Reversed $\mathrm{CPC}^{* *}$

Interpretation and Evaluation of Clinical Laboratory Data

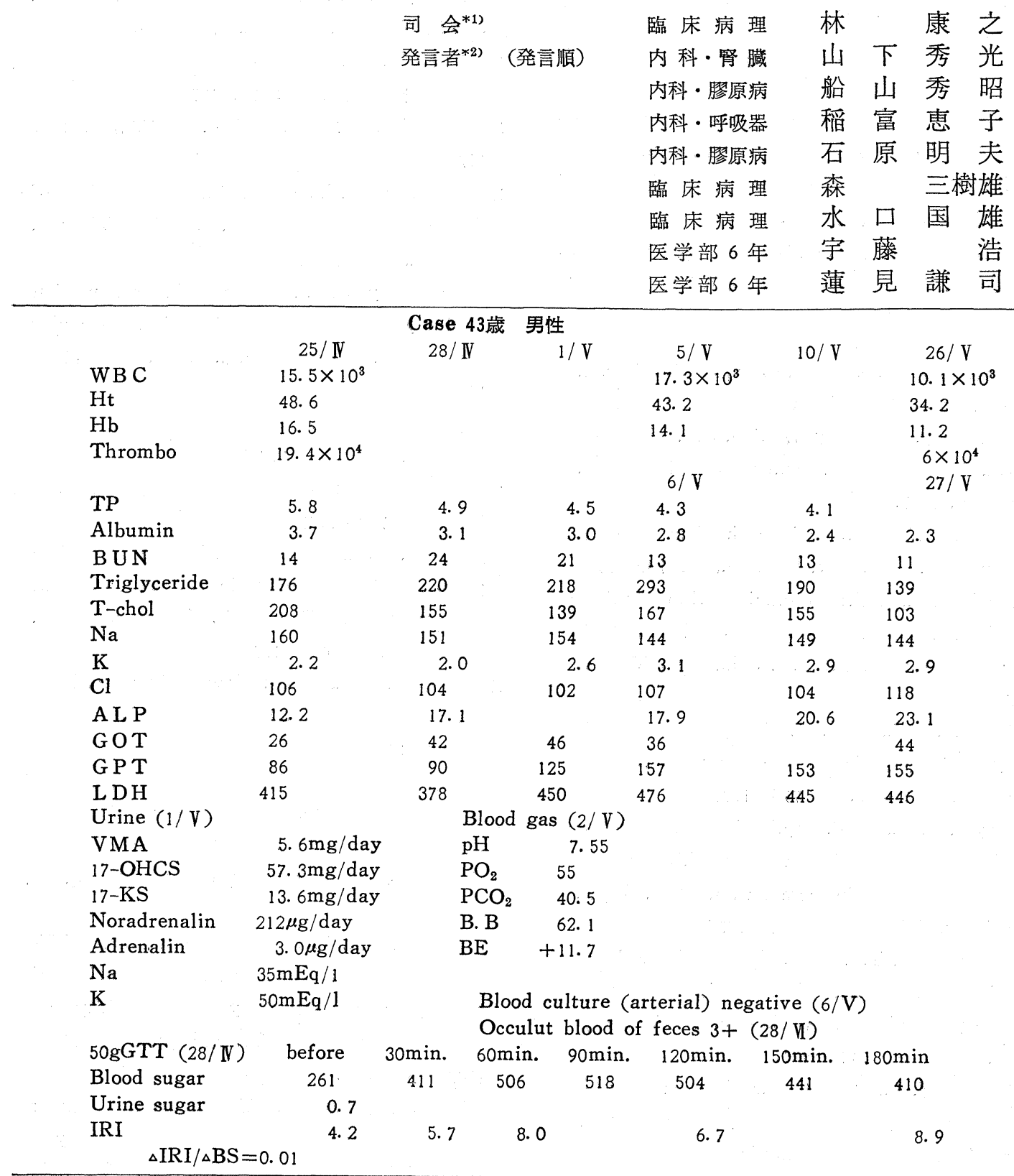

*1) 順天堂大学助教授 (臨床病理学教室)

Department of Clinical Pathology, Juntendo University, School of Medicine.

*2) 順天堂大学医学部

** 第207回順天堂医学会学術集会〔Nov., 18, 1978〕（Jan., 13, 1979 受付） 
林 (司会) 今日は reversed CPC ですが，これ は私ども，検查成績になれていただくために授業 でもやっているものであり，診断を当てろという ことではございません，診断が当たっても，当た らなくても，ただ，その検査の意味するところを 正確に考学てほしいといらことです．㫮様方のお 手元へお配りした検査データ，これは 1 症例の全 経過を通じてのデータが載って於ります，患者を 見るときには，全経過を通じてのデータは見られ ないわけで, 1 回1回しか出てきていない。つま り，経過ごとに新しいデータが加わっていくとい らことですから，そのときそのときの病態を考光 ていただかなくてはならないというわけです。 そ れを全部まとめて出してありますので，ある程 度，全体としてつかんでいただくことは可能では なかららかと思います。

今日和話しいただく先生方はあらかじめお源い してございますけれども，最初に学生諸君の中で 最高学年の方に，どんなことを考えたかを 1 人， 2 人，発表していただきたいと思います。

一応データについてご討論願ったあとで臨床経 過を打出しします。そこで，何か意見があればい ただきますし，なければ剖検所見を説明していた だいて，それから最後のディスカッション，とい う順序で進めたいと思っています。

まず学生代表として宇藤君，お願いします。

宇藤 入院から死亡するまでの検査成績につい て, 経過を追って述べてみます. 入院時の血液検 查では, 白血球数が 15,300 と増加しているほか は, 貧血所見もなく，血小板数も正常です. 白血 球数は経過中も増加を示しておりますが，5月26 日には $\mathrm{Hb}, \mathrm{Ht}$ ともに軽度減少し, 血小板数も減 少を示して和ります。

total protein は全経過を通じ低值を示し，アル ブミンも正常下限で, 経過と共に漸次低下傾向を 示して打ります。

$\mathrm{BUN}$ は，4月28日，5月1日にやや上昇して いる以外は，正常範囲内にとどまっており，血清 triglyceride は入院時より上昇傾向《あり，最後 の 5 月26日には正常值内に下がっています. total cholesterol は, 正常範团内での変動で 于.

次に, 電解質の変化飞 5 つりす。. Na は 4 月 25日に上昇して和りますが，以後は正常值内です。 K は全経過を通じてかなり低值を示しておりま す. $\mathrm{Cl}$ は正常值です.

血清酵素は, Al-Pは入院時は正常上限でした が，徐々に上昇し，5月26日では正常の倍ぐらい になって抢ります。

GOTは正常範囲ですが，GP T が上昇してお り，経過と共に次第に上昇して和ります，L D H は正常範囲. 次に特殊検査に入ります。 5 月 1 日 の尿検査所見ですけれども，VMAは正常範囲， 17-O H C S はかなりの上昇，17-K S は正常上限 です. adrenalin は正常下限ですが, noradrenalin が上昇しています。

血液ガス, $\mathrm{pH}$ が上昇し, alkalosis の状態で す. $\mathrm{PO}_{2}$ は低下, $\mathrm{PCO}_{2}$ は正常域, base excess が +11.7 ということで代謝性 alkalosis にあるので はないか。

便潜血反応は陽性を示し，消化管出血があった わけです，GTTの成績は，この結果からいうと 糖尿病域にあると思いますが，IRI/BS の值は 0.01 ，これは 0.7 以下の真性糖尿病域と考兄てい いのではないかと解釈しすす。, 以上, 一通り, 臨 床検査值について解説しました。

林一応説明していただきましたが，それ以外 のことでつけ加觉ることがあれば，蓮見君どれと ぞれがメインで，どらいら変化が非常に著明な変 化だということをまとめて指摘してください。

蓮見 別につけ加えることはないのですが，と くに私が気になったのは, 血清 trigly-ceride が上 昇していること. K が全経過を通じて下がってい ること. total protein るちょっと下がっているこ そ. Al-P, GPT の上昇があること.

あと，尿所見で VMA は(一)で, 17-OHCS が 上がっているということ，それから， noradrenalinが高くて, adrenalin は下がっているというこ と. 血液のほうでalkalosisを示しているというこ と, GTT で primary の DM のパターンをとっ 
ているのではないか，といらことです。

林 いま 2 人の来年卒業する学生諸君に预話し 願いましたが, 電解質とBUN, 総蛋白を含め て，内科の山下先生何かご意見いただけません か.

山下 検查結果から，ある程度診断のところま でいってょろしいのでしょらか.

\section{林 結構です.}

山下 生化学検查から見ますと，T P が経過と ともにだんだん落ちてきています。それと，GOT - GPT・Al-P・LDHの上昇, total Cholesterol, triglyceride の低下からこの TP の落ちてきてい るのが, liver cirrhosis が存在するのか，あるい は，食事が全く入らなくなって TP が落ちてきて いるのか，ということが一応考兄られると思いま 于.

あと，この中で一番問題なのはKが非常に低い ということです。このKの低いというのが，どう いう状態で起こってきているかということですけ れども，尿の泣らを見ますと，尿中のKの排泄が 非常に多い。ですから，これは腎前性ではなくて 腎臓からのK排泄が多いといらことが，こういう 低K血症を呈している原因だと思います。

そこで，17-OHCS が上がってきている，noradrenalin が上がってきている. それから Na が最 初に上昇してきて和ります。といらことからする と，何か高血圧があるのではないかということ が，まず考觉られると思います。

Kが低い状態からすると， secondary の aldosteronism といら状態なのか，あるいは，副腎皮 質から aldosterone の分泌が增加しているのか， そういうことが考えられると思います。

ということからすると，17-OHCS が上がって きて， aldosterone 系も上昇しているょうな高血 压といらことになりますと，ACTHの分泌過剩が あるのではないかといらことを考党なくてはいけ

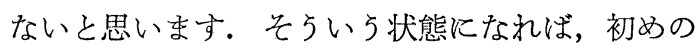
よらにNaが上昇してくると考光られます。

それで，一つは異所性のACTH産生腫演が考兄 られて，鑑別としては，その primary がどこらへ
んかといらことになりますが，一番多いのは肺癌 なんですけれぞも，あとは GTT のほうの異常が あるので，それからすると，膵癌からの異 所性 ACTH産生腫湟か, あるいは多発性の内分泌腺腫 というものがあるのかどうか，といらことも一つ 考えなくてはいけないのではないかと思いすす。

林 有難うございました。いま GTT の話が出 ましたが，船山先生お願いします。

船山 GTT のことが問題になっておりますが， basal insulin level を見ますと 4.2 であり, 問題 ないと思います．ところが， 30 分での $\triangle \mathrm{IRI} / \triangle \mathrm{BS}$ が，先ほどの宇藤君もいわれたように，正常では 0.7 以上ですが，この症例の場合，0.01 と非常に 下がっております。

しかし，その後の insulin response は少ないが 僅かに反応しており，また血糖值もやや下降して おります。即，血糖值はかなり高い值を示してい るが重症糖尿病とはいいがたい.

このようなタイプを呈する臨床的な疾患として は, primary， secondary の両方を通じて，血糖 值が異常に高い場合， primary， secondary の別な くインスリンが低下します。この症例のように血 糖值が上がってインスリンの分泌が少ない疾患は secondaryでは何かと申しますと, pheochromocy toma とか，あるいは pancreatitis といったもの が挙げられます。

しかしこの症例ではFBSが高すぎ，これらの疾 患にあてはめるには，少し無理があると思われま すे.

それから，いま山下先生のほうからいわれた pancreas の carcinomaについてですが, pancreas にはラ氏島の中に $\alpha$ 細胞, $\beta$ 細胞がありまして, 前者から glucagon, 後者からインスリンが分泌さ れて抢り， carcinoma の大きさ，種類によっても 違いますが，小さいうちには通常両方相殺されま して，耐糖能異常を呈さないということがいわれ ています。

それから，Kの低下といらことが問題になって いるわけですが，K欠乏と耐糖能異常ということ は前からいわれており，非常に関係があるわけで 
†.

たとえば，サイアザイド系の薬剤投与，あるい はK制限色の場合, るるい低K血症のある primary aldosteronism では, $50 \%$ 以上の耐糖能の低 下を見るという報告がなされているように，糖尿 病にK代謝が関係するといらことはわかっており ますが，その機序は不明のようです。

この症例の場合において GTT curve が clear に説明できないのは，K 欠乏も関与しているかと 思われなす。

林この血糖值の上がったということに対し て，何か他に関係づけるとすれば，Kが二番でし ょらか。をそれとも他に何かございますでしょう か. 尿所見と結びつけるのか, 血清 $\mathrm{K}$ 值と結びつ けた注5がいいのか，あるいは，これは独立のも のなのかといらことなんですけれども.

船山 Kが下がった場合での耐糖能異常の可能 性は先汪ど申し上げましたが，耐糖能の grade と 血清K值における明確な相関関係は，私はまだ報 告を見たことがありません。この症例のように炎 症性疾患, 肺疾患, 生化学的検査異常なぞの多種 多様の疾患下では, GTT・IRI・尿糖からの分析 診断は困難だと思います。

林 有難らございました。 あと低K血症と関係 がございますが, alkalosis——血液がスはここに は1回だけしか書いてございませんけれども，病 歴を見ますと何回もやっておりまして, 全部同じ ような結果が得られております。この点につい て, 稲富先生, 少し和話し願光ませでしょう か.

稲富 $\mathrm{PO}_{2}$ は全部低かったんでしょらか。

林 経過中に 4 回調べて㧍りますが，全部低い んです.

稲富 先ほどいわれましたように，これを見ま すと，明らかに代謝性 alkalosisが認められます。 buffer base は普通45から55ぐらいですが，それ がちょっと上がっていますし， base excess とし ても普通は $0 \pm 2$ とか, $2.3 \mathrm{mM}$ ですけれども,

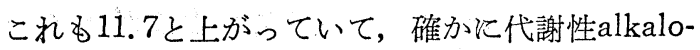
sisですね.
そういう場合に，呼吸性の代償機構が少し働い て, alveolar hypoventilation 気味になることは なるんですけれども，たた， $\mathrm{PO}_{2}$ が $55 \mathrm{mmHg}$ とい うと正常に比べてだいぶ低い。

ですから，胸の写真などがないのでわかりませ んけれども，肺内に病変があるか一応 $\mathrm{T} P$ なども 低いので，胸水か何かたまっているかもしれない と考兵す。これを見た限りでは代謝性 alkalosis の状態ですが，それを代償するところの呼吸性の 代償だけでは，この $\mathrm{PO}_{2}$ は説明がつかないように 思います。

それでこの代謝性の alkalosisは，Kが非常に低 いということと結びついて考学らると思いま す.

林 有難うございました. あとの 3 回のデータ

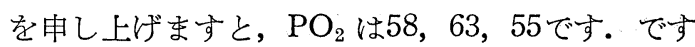
から低いということは非常に重要な意味を持って いるのではないかと思われます。

最後に石原先生にデータをまとめていただきた いと思います。 ホルモンのデータもまとめてお願 いします。

石原 初めに尿中のホルモンについて申し上げ ます。

vanillylmandelic acid $の$ 正常值は, 4.7〜11.4 $\mathrm{mg} /$ day ですから，この症例では $5.6 \mathrm{mg} /$ day とい らことは正常範囲内です.

それから，17-OHCS ですが，正常值は 2 〜 $\mathrm{mg} /$ day ですから， $57.3 \mathrm{mg} /$ day というのはかな り高い值であるといえます。

次に17-KS ですがこれは男性と女性と違います が，男性の 1 日の尿中排泄の正常值が $10 〜 15 \mathrm{mg}$ です。この患者は $13.6 \mathrm{mg} /$ day ですから, 正常範 囲内にあります。

次に, 尿中のnoradrenalin は 1 日の正常值が 10 〜 $50 \mu \mathrm{g} /$ day ですので，この方は $212 \mu \mathrm{g} /$ day で すので非常に高い值です．尿中 adrenalin の正常 值が $1 \sim 10 \mu \mathrm{g} /$ day ですから，この $3.0 \mu \mathrm{g} /$ day で すから正常值です. 臨床上, noradrenalin とadrenalinを加えて $100 \mu \mathrm{g} / \mathrm{day}$ を越えるような場合に は異常と考学ていい，従いまして，この症例では 
尿中の carecholamine が高いレベルにあると考兄 られます。

それから，尿中の $\mathrm{Na}$ は $35 \mathrm{mEq} / l$ ですが，1日の 尿中の正常值が，順天堂大学の中検では 4.3 5.0 $\mathrm{g} /$ dayです.この場合は $35 \mathrm{mEq} / l$ の 2.3 倍にした值 が $80.5 \mathrm{mg} / \mathrm{d} \boldsymbol{l}$ ですので, これに尿量を掛けない といけないのですが，正常より低い值にあると考 えられます。

それから尿中のKですが，正常が $2.5 \sim 3.0 \mathrm{~g} /$ day です.この場合, $50 \mathrm{mEq} / l$ ですから, それを 3.9 倍して $195 \mathrm{mg} / \mathrm{d} \boldsymbol{l}$ ，それに尿量を掛けますと， 大体これは高い值になると思われるす。

これまでの検查結果から，尿中の $\mathrm{K}$ の排泄が多 く, 低K血症を認め, 尿中の catecholamine の増 加, それに尿中の 17-OHCS が非常に高い状態に あるとい充す。17-OHCS というのは, cortisol の尿中の代謝産物ですから，cortisol が過剩に分 泌されている状態があるのではないかということ が，まず考学られる思います。

次に, 尿中の $17-\mathrm{KS}$ は正常值にあること, 尿中 の catecholamine 中の noradrenalin が著增し, adrenaline は注济正常範囲内にあることなどから 考えまして，副腎皮質の腫瘍によるものではない ものと考学られます。この患者の全身状態の一つ の指標として total protein が非常に低いという ことと，耐糖能の異常があるとい5こと，その上 代謝性の alkalosis があることなどを考㝋た場合 に, pancreas K Krebsがあって，それが一つの大 きな原因となって ectopic ACTH producing neoplasma によって莣起されたいわゆるCushing 症 候群を呈したのではないかと考党ています。

林 pancreas とすると，これは隠したわけでは ないのですが amylase のデータがないですね。 そ れからビリルビンが高くないようですが。

石原 pancreas krebs の場合に, pancreaskopf ですと，血中のビリルビンが高くなってくるわけ ですが，体部の場合であれば，それ汪ど高くなら なくてもいいのではないかと思います。

林どうも有難うございました。

それではレントゲン写真と, 患者の現病歴, 経
過をご覧に入れたいと思います。稲富先生，ぞう ぞレントゲンをご覧になってください。

(レ線写真供覧)

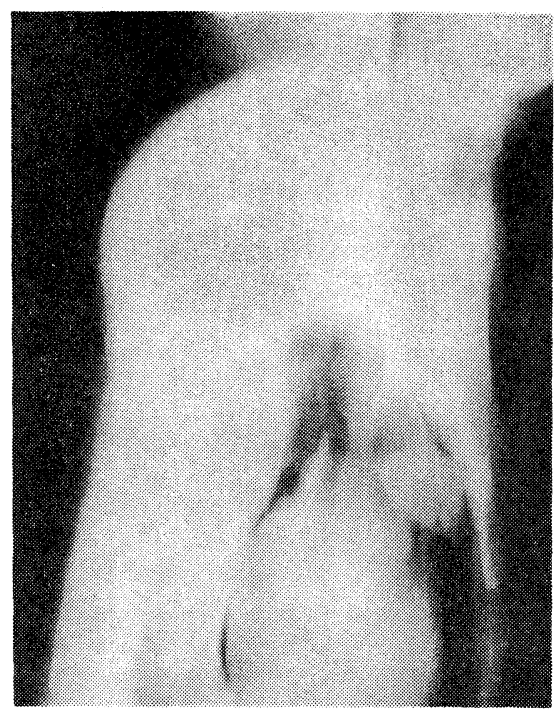

胸部断層撮影（ 5 月13日）

稲富 胸部写真ですが，一番左が 53 年 1 月 28 日, 真ん中が 5 月 13 日, 右が 5 月 26 日の写真で す. 下の断層写真は，3枚とも5 月13，14日のお たりで撮っています。

一番最初の 1 月 28 日の写真ですけれども, この 正面像では, 右の下肺野, 心臟寄りのところに境 のはっきりしない陰影が認められます。とれから 心臟の第 2 弓のところに, 心陰影と別個にちょっ と出っ張った場所があります。大ささはだいたい $3 \mathrm{~cm}$ ぐらいの半円形で, Grenzがはっきりしてい るような陰影です。

この方は血圧が高いんでしょうか，上縦隔のと ころの陰影がわりにシャープで, 少し白っぽいの がありますので，ここのところは血管性の変化で 縱隔が幅広いのではないかと考学られます。

5 月13日の写真ではここに認められた半円形の 陰影が，条件は違いますがかなりはっきりしてき ました，肺野の所見は，中肺野，並びに下肺野は あまりきれいではなく，散布性の陰影がありま 于. 
5 月 26 日の写真では, 右側に胸水と思われる陰 影があります。あと左の下肺野に，下肺野ばかり でなく，上のほうにも少し陰影があります。左側 には胸水はありません，断層写真では, 中下肺野 のところにちょっと斑点状の陰影があります。出 っ張っていた半円形の陰影は, 側面像で見ると, 前縦隔のところに認められます．5月13日の写真 で, weichteil のあたりがデコボコして, air density が見觉ます.縦隔および皮下気腫を起こして います。そんなところです。

林 あとも5一つ副腎と肝臓のシンチグラムが ございます，石原先生，ご覽いただけませんでし ょらか.

石原 左側に肝臟のシンチグラムが提示されて おりますが，この核種は ${ }^{99 \mathrm{~m}} \mathrm{~T}_{\mathrm{C}}$ ですか。

林 $\mathrm{T}_{\mathrm{C}}$ です。

石原 このシンチグラムの右側には肝臓が検出 され，左側を見ますと，淡く脾藏が描写されてお ります。まず胍藏の形ですが比較的スムーズであ るということと，肝内の $\mathrm{T}_{\mathrm{C}}$ の分布の度合いがだい たい均一である。中に取り込久の悪いよ5な部位 が認められない。さらによく見ると，肝内部のあ たりに強いて申しますと，多少取り込みが悪いか と思われるところと, 肝の左葉が少し出っ張って いるのではないかということが考兄られるんです が，これは解剖学的形態を示し，全体的に申し上 げると異常ないものと存じすす。なにせシンチグ ラムというのは, 厚い肝臓のある部分を slitでと っているわけですから，幾つか断層のようにして とっていくと，よりはっきりすると思いますが， この Hilus のところを所見としてとっておくとい らことと，腫瘍性の変化一一何か腫瘍によって取 り込みの悪いところがあるのではないかという感 じがします。これは感じとだけしか申し上げられ ないんですが—。

それから副腎のシンチグラムについてですが， これは核種が ${ }^{131} I$ のコレステロールだと思いま す. 両側の副腎ともかなり ${ }^{131} \mathrm{I}$ コレステロールの 掑取率の高い部分が認められ，従って副腎は左右 両葉とも，非常に肥大しているだろうということ

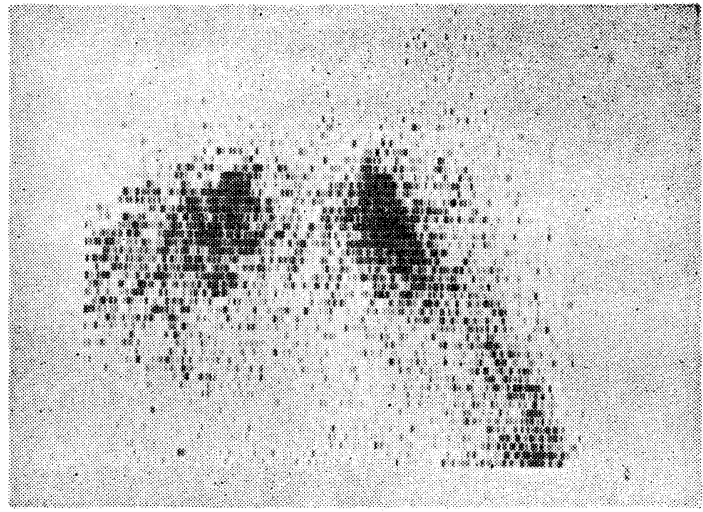

副腎シンチグラム

が考党られます。上です。

林 ぞらも有難らございました．簡単に入院後 の経過を紹介いたします。（次表参照）

次に剖検所見を，森先生に求願いしたいと思い ます。

その前にこれは特徵になるかならないかわかり ませんが，熱はそんなにないんですけれども，非

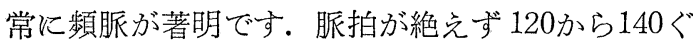
らいあったということで，患者が入院中常に興奮 状態にあったといらことが，ここからも㧍わかり いただけるのではないかと思います。発熱は最後 のころに肺炎を併発してから，少しだけ出ており ますが，日常はほとんぞございませんでした。そ れでは森先生，お願いします。

森 剖検所見を申し上げます。（スライド1） これ㭠ほど気縦隔撮影で写っていた丸い陰影

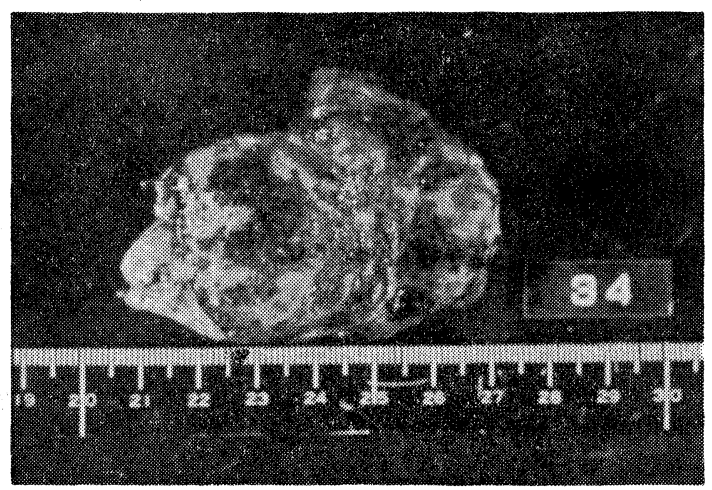

スライド 1 胸腺腫瘍の割面 
〈患 者> 福○政○ 43才, 男性, クリーニング業.

$<$ 初 診> 昭和53年1月21日

＜主 訴> 手指のしびれ感, 多飲多尿, 全身僚急感, 浮腫 (顔面, 足背), Acne 様発疹, 色素沈着 (顔面, 頸部, 前胸部), 口腔内白斑.

＜現病歴＞ 昭和52年10月より某医院にて高血圧指摘され，降圧剤を投与されていた. 昭和53年 1 月10日：口腔内白斑汇気づき，某耳鼻科受診し，汎口内炎の診断を受ける.

1 月 18 日：当院総合健診受診し, 右下肺野異常除影, 拘束性換気障害, GPT 101 単位, LDH554 単位, 低 $\mathrm{K}$ 血症 $2.6 \mathrm{mEq} / l, \mathrm{WBC} 15000, \mathrm{CRP}(+), \mathrm{Wa}-\mathrm{R}(+)$, 蛋白尿, 収縮期雑音, 軽度陳 旧性下壁硬塞, $50 \mathrm{gGTT} / 1 \mathrm{~h}$ で血糖 $200 \mathrm{mg} / \mathrm{d} l$ を指摘される.

1月21日：総合健診より，内科へ紹介されKeflex 1.5gを9日間投与. 口腔病変も梅毒性? とい ろことで，某耳鼻科で Syncillin 60万単位 3 週間投与されたが，軽快せ姉た。.

2月17日：東京医大皮膺科へ紹介され，Lues latens，口腔 candidasis, Acne senilis Senile sebaceous hyperplasiaの診断で, Furgizone Syncillin, Minomycinなどの投薬を受けていた. 同時飞, 2 月初め頃より顔面紅潮, 顔面, 頸部, 前胸部にExanthema出現. 2 月中旬より手指シ ビレ感，全身倊欱感，多飲多尿となる。次第飞全身僚㤐感増強し，3月中旬より，下肢が持ち上 りとくく階段昇降困難となる．3月末より浮腫出現し，4月10日頃浮腫著明となったが，飲水制 限で軽快した.

4 月 20 日: 食後 2 時間血糖值 $514 \mathrm{mg} / \mathrm{d} l$.

4 月24日: 内科入院.

$<$ 入院時現症 $>$

身長 $160 \mathrm{~cm}$, 体重 $47.5 \mathrm{~kg}$, 血圧 $170 / 90 \mathrm{mmHg}$, 脈 $100 /$ 分, 整, 意識清明なるも, 精神状態やや 興禽状態. 頭皮膚発赤 $(+)$, 顔面, 頸部, 前胸部飞発赤, 色素沈着, Acne様発疹 $(+)$. 顔面やや 浮腫状, 足背飞浮腫 $(+)$, 舌, 口腔粘膜飞白斑 $(+)$, 肺 : 右下肺野飞ラ音聴取.

<入院時検查所見 $>$

RBC $356 \times 10^{4}$, WBC 15,500 (My 1.5, St 8, Seg 82.5, L 6, M 2, toxic glannule(+)), Th 19. $4 \times 10^{4}$, Reticulo $11 \%$, BSR 60分 $6 \mathrm{~mm}$, 出血凝固正常, T. P 6.2, A/G 2.6, Al 72.9 $\%, \alpha_{1} 3.1 \%, \alpha_{2} 6.1 \%, \beta 12.2 \%, \gamma 5.7 \%, \mathrm{BUN} 14, \mathrm{Na} 160, \mathrm{~K} 2.2, \mathrm{Cl} 106, \mathrm{Ca} 4.9$, $\mathrm{PO}_{4}$ 3. 4, Al-P 12. 2, GOT 26, GPT 86, LDH 415, T-Bil 0. 8, $\gamma$-GTP 124, LAP 207, LDH isozyme: I 36.8, II 37. 8, III 16.5, IV 3. 4, V 5.5\%, CRP 2+, 梅毒血清反応: $\operatorname{VDRL}(+), \operatorname{Agg}(+), \mathrm{CF}<5$ dil.

䯣液：水様透明, 初圧 95, 終圧 70, 蛋白 $34 \mathrm{mg} / \mathrm{d} l$, 糖 $185 \mathrm{mg} / \mathrm{d} l$, 細胞数 $4 / 3$.

\section{$<$ 入院後経過 $>$}

入院当日より興奮して，大声を出したり，幻覚を訴えたり等の精神症状が見られた.

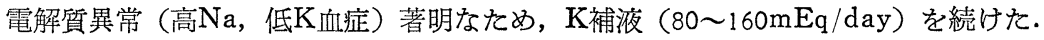

空腹時血糖 $300 \mathrm{mg} / \mathrm{d}$ l前後, 1 日尿糖量50 $100 \mathrm{~g}$ あり， 5 月 2 日より, lente insulin 開始した が，精神症状強く，食事摂取の不規則などあり，コントロール困難であったが，1 カ月後には lente insulin 30単位でほぼコントロールされるようとなった。

血中，尿中ステロイドの高值あり，17-KS $13.6 \mathrm{mg} / \mathrm{day}$ の上昇に比し，17-OHCS57. $3 \mathrm{mg} / \mathrm{day}$ と著明に上昇していることょり, 異所性 ACTH 症候群を考光た．精神症状が多少落ちついたので,

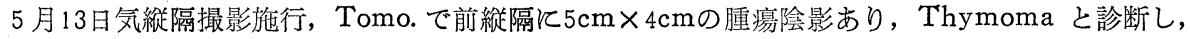
糖尿病コントロール後 Ope を考光たが，全身状態改善されず，肺炎併発し，5月25日よりViccillin 2. og 投与したが， 5 月 27 日食残少量誤飲し，呼吸停止をきたし，午後 2 時 14 分死亡.

〔附 記〕 1 血中ホルモン定量

$$
\begin{array}{crr}
\text { ACTH } & 3550 \mathrm{pg} / \mathrm{m} l(26 / \mathrm{V}) \\
\text { Aldosteron } & 3.2 \mathrm{ng} / \mathrm{d} l(3 / \mathrm{V}) \\
11 \text {-OHCS } & 153 \mu \mathrm{d} / \mathrm{d} l(1 / \mathrm{V}) \\
2 \text { Dexamethason } & \text { 抑制試験 } & \\
17 \text {-OHCS } & \text { 前 日 } & 83.8 \\
& \text { 第1 日目 } & 63.8
\end{array}
$$


です. 前縦隔に大きさ $6.5 \times 3.5 \mathrm{~cm}$ の境界明瞭な 胸腺腫瘍で久られ，一部出血しております，重さ は50gありました. 腫瘍の割面は白色をしたtumor があるところと，また一部出血している場所がか

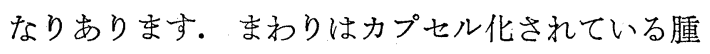
湟です.

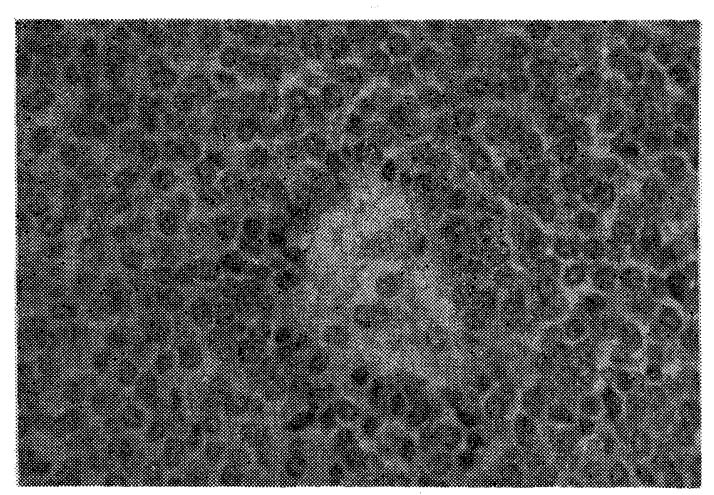

スライド 2 カルチノイド腫瘍

スライド 2 はその顕微鏡写真ですが，主に核が 丸型で細胞質の少ない，また一部丸い集団を作っ ている腫瘍です，場所によっては，腫瘍血管を持 ち，ロゼット形成といっていいような所見があり ます. carcinoid の腫瘍といわれるものであり ます. 以前は，こういうのを thymoma という範 疇に含めていたんですけれども, 最近は AFIP の 分類によって, carcinoid 症候群——arcinoid tumor というふらに分類して和ります。

腫瘍の高倍率像では, 核が円形, あるいは楕円 形をしておりまして，細胞質は比較的少ないよう な細胞です.

この腫瘍の一部をとって，それをホモジナイズ ドして，その腫瘍細胞中に含まれている ACTH とセロトニンを測りましたところ，ACTH が 47 万 $\mathrm{pg} / \mathrm{m} l$ といらことで非常にらえているわけで す.セロトニンも $306 \mathrm{ng} / \mathrm{m} l$ あることがわかりま した。腫瘍細胞の電顕像では原形質に secretion granule が出現して和ります。

右の肺には，このように結節を作った白色をし た浸潤があり，abscessを形成しております。培 養ではKlebsiella が出てきて拈りまして，Kleb- siella pneumoniae による肺炎だと考劣まし た. 腎臟にも abscess を作って, 細胞浸潤がみら れます。

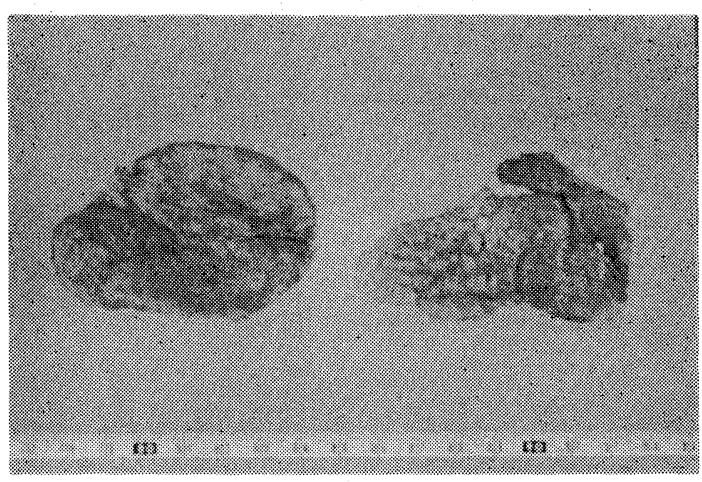

スライド 3 副腎

副腎は, 右が $21 \mathrm{~g}$, 左が $25 \mathrm{~g}$ と, 正常の 3 倍から 4 倍近くの重さがありまして, 高度の hypertrophyを起こしています。（スライド 3 ）

（1）腫瘍組織中飞拈ける有意のホルモン含量

（2）血中・尿中ホルモン值の増加

(3) 当該ホルモン過剩による臨床所見

(4) 腫瘍摘出による臨床所見の改善

(5) 電子顕微鏡飞よる分泌顆粒の存在

(6) 組織培養や移植とよるホルモン放出

（7）当該ホルモンを産生する内分泌腺の萎縮

スライド 4 異所性ホルモン産生腫瘍の診断条件

異所性ホルモン 産生腫瘍を診断する場合の条件 としてはまず最初に，腫瘍細胞中に多量のホルモ ンが含まれていなければならないということ，次 に，血中・尿中のホルモンの值がふえていなけれ ばならないこと、それからホルモン過剩による臨 床所見が出ていなければならないこと．あと腫瘍 摘出によって臨床所見が改善すること. それか ら，電顕によって分泌顆粒があるということ．組 織培養とか，移植によってホルモンが放出される こと、また，そのホルモンを産生する内分泌腺が 萎縮する場合が多いということです。

これを全部持つということではなくて，このう ち幾つかの条件を満たしている場合が多いわけで す. (スライド 4 ) 
一番重要な条件は, 腫煌細胞中にホルモンが多 量に含まれているということです。この症例で も，腫瘍細胞中のACTHが多量に含まれて抢り， 血中, 尿中ホルモンの増加, 臨床症状, 電顕で分 泌顆粒の証明などより 異所性ホルモン産生腫瘍と いって間違いないと思いすす。

\begin{tabular}{|c|c|c|}
\hline & \multicolumn{2}{|c|}{ 症 例 数 } \\
\hline & 井村 5 & Liddle 5 \\
\hline 肺癌（気管支癌） & 86 & 52 \\
\hline 気管支腺腫 & 14 & 5 \\
\hline 胸 腺 腫 & 25 & 11 \\
\hline 縦 隔 洞 癌 & 9 & 2 \\
\hline 膵 臟 癌 & 23 & 11 \\
\hline 甲状腺腫瘍 & 10 & 2 \\
\hline 卵 巣 腫 瘍 & 8 & 2 \\
\hline 前 立 腺 癌 & 6 & 2 \\
\hline $\begin{array}{l}\text { 褐色細胞腫 } \\
\text { (Paragangliomaを含む) }\end{array}$ & 6 & 4 \\
\hline 乳 癌 & 4 & 1 \\
\hline その他 & 25 & 12 \\
\hline 計 & 216 & 104 \\
\hline
\end{tabular}

スライド 5 異所性 $\mathrm{ACTH}$ 産生腫瘍の世界の報告例

(井村裕夫 : 臨床科学 6,1473,1970 より)

異所性ホルモン 産生腫崵にはいろいろなものが ありますが，一番多いのがACTHを産生する腫瘍 で，そのうち肺癌，とくに oat cell carcinoma が 多いようです. その他, 肺の腺癌, あるいは今度 の場合のような胸腺腫瘍, それから直腸の carcinoid などがあります。

$\mathrm{ACTH}$ 産生腫瘍に次いで多いのが副甲状腺の木 ルモンを産生する腫瘍で，これでもやはり肺癌が 多い上5です。 その他肝藏とか, 胆囊癌・腎臟癌 でも見られます。

その他, セロトニン・ADH ・ 性腺刺激ホルモン などを分泌する腫湟もあります。

この他に多臓器に腫演ができて, その腫瘍に見 合った臨床症状が出てくるというものがありま す.これらを multiple endocrine adenomatosis というふらに呼んで抢りまして，略して MEA と
いっております。

現在では type I と II があり, type I が Werner's syndrome と呼ばれ, pituitary と pancreas と parathyroid, この 3 つの場所に腫瘍ができ るもので, type II とういのは Sipple's syndrome といいまして, parathyroid と thyroid と adrenal gland に腫瘍ができる場合です.

この症例では, pituitaryはとくに異常ありませ んし, pancreasにも異常はみられませんし, parathyroidにも異常はなかったわけですけれども, 一応説明しますと, type I の症例では, pituitary では, non-functioning にたた腫湟ができて増殖 する場合と，ACTH・MSH を分泌して Cushing 症候群を呈する例，それから，growth hormone を分泌して acromegaly，あるいは giantismを起 こす場合，また parathyroid hormone が分泌さ れて hypercalcemia を起こす場合などがありま 于.

pancreas の場合は, gastrin を産生する腫瘍で はZ Zollinger-Ellison症候群が起こりますし，イン スリンの場合は hypoglycemia が起こります.

それから, VIP—これは vasoactive intestinal polypeptideですけれぞも，この場合は非常に 下痢を伴 5 WTHA 症候群を起こしすす。その他 $\mathrm{ACTH}$ と MSH を分泌する Cushing 症候群とい うことになります。

type II のSipple 症候群の場合は, parathyroid から parathyroid hormone が出て hypocalcemia を起こす腫瘍，また thyroid のC細胞からできる medullary carcinoma, この場合はカルチトニン が出てCaを下げます。その他副腎からは catecholamine が分泌されるような pheochromocytoma， こ5いら3つのものがいっペんに出てくる場合を type II といいますす.

以上のようなことで，この症例では，胸腺にの み $\mathrm{ACTH}$ を分泌する腫瘍が見られました。

林どうも有難うございました。

この症例は昨年の 10 月に高血圧が見つかってか らといらことですが，病歴を見ますと，結局，診 断が確定したのは 5 月でありまして，その間約半 
年たっております。先生は先ほど，いとも簡 単に異所性 ACTH 産生腫瘍で, 高血圧もあった んだろうと拐っしゃったわけですが，高血圧が主 訴であるとか，あるいは血圧が高いということが 見つかった場合の臨床的な検索の進め方を話して いただけませんでしょうか。

山下 スクリーニングとしては，まず上下肢の 血圧を測って，上下肢の左右差があるかないかと いうところから始めなくてはいけないと思いま す.

あと，検查的に高血圧をみていく上で大事なの は，その中でも内分泌性高血圧を否定するという ことが一番必要なことですし，それから renal vascular hypertension も否定していかなくてはい けないということが必要ですから，まず副腎皮質 から分泌されるホルモン系統の測定, それからレ ニン活性の測定, あとは, レニン活性について刺 激試験という方法でやりまして，レニン活性が過 剩反応をするかどらかということで，腎血管性高 血圧かどうかというのは，ある程度診断がつくと 思います。

そういうことで， レニン活性が低いか高いか で，ある程度診断の範囲が狭まってきますので, レニン活性の高い疾患の場合には腎血管性高血圧 ということ, おとは本態性高血圧の中の高レニン 性の hypertension がありますし, 悪性高血圧・ Robertson-Kihara 症候群という, 要するに J G cell tumor の場合もありますし, そらいうことが だんだんわかってくると思います。

レニン活性が低い場合には，血清の $\mathrm{K}$ 值を注意 して見ていかなくてはいけないと思います。そう いら場合には, primary aldosteronism とか, 䤉 素欠損症，その中でも 11- $\beta$-hydroxylase 欠損と か, 17- $\alpha$-hydroxlase 欠損とか, 突発性アルドス テロン症とか, あとコルチコイドの反応性の高血 圧，本態性高血圧の中の低レニン性の高血圧とい ららうにそという高血圧がだんだん分類されて いくと思います.

林 有難うございました。どなたかご意見ござ いませんか，病理解剖診断についても何かござい
ましたら一一。

山下 臨床経過と検査データが一番食い違うの がK值なんです。これは52年からの hypertension がありますが，このときの降圧剤によって低くな っているのか. しかも，血中ホルモンを見ます と，アルドステロン分泌が正常なんです．こ5い うことからすると，これだけKが低くなってき て，尿中の $\mathrm{K}$ 排泄が非常にたくさんあるというこ とが，ちょっと説明つかないと思うのですけれど ל.

林 既往歴のところを見ますと，低Kを起こす ような薬剤は投与されていないようです。精神安 定剤のようなものばかりでございまして，降圧利 尿剤は出されていないようです。

山下 そうすると，このKが低いのはどこから きたんでしょうか。

森ここの正常值はアルドステロンが 0.1 から $1.2 \mathrm{ng} / \mathrm{d} l$ ですから, 3.2 というとやはりふえてい るんです.

林 山下先生, いまの薬ですけれども, セレナ ール・レチナミン・トリアムテレンなどは服用し ています，他にございませんでしょうか。

水口 肝臟の所見が病理の中にないんですが, 肝細胞の変化はどうなっているでしょうか.と いうのは，GOT があまり上がっていないのに， GPT が非常に上がっていますが，そういうこと で，何か変化があったかどうかお聞きしたいんで すが.

森 肝臓の注うは, 炎症性の変化, あるいは肝 炎を思わせるようなもの, portal triad に何か炎 症を思わせるようなものとか, 肝硬変とか, そう いったものはとくにありませんでした。

水口それでは，この GPT が高くなっている というのは，どういうふうに説明したらよろしい のでしょらか.

林 主治医がおられませのでちょっとわかり ませんが，Al-Pも上がっていますし，多少は肝実 質細胞が壊われていたのではないかと，私も推定 していたんですけれども，組織像としては何とも なかったでしょらか。そうなるとわからないんで 
すが——.

他にございますか，石原先生，いかがでしょう か.

石原 臨床検査のデータを拝見しますと，total protein が6.2なんですが， $\gamma$-globulin が5.7\%, $\mathrm{A} / \mathrm{G}$ 比が 2.6 ，かなり高い状態にあるとい5こ と，そのへんについて，逆に私のほうからおうか がいしたいと思っていたんですけれども。

$r$-globulin が低くて，A/G 比が2.6と高い状態 汸ったということですが，その $r$-globulin が非 常に低かったということは，ぞう执考えでしょう か. 免疫電気泳動をやっていらっしゃるでしょう か.

林 免疫電気泳動はやっておりません。

Al-P の isozyme と LDH の isozyme のみです. 確かに $\gamma$-globulin は非常に低くて5.7\%です。 そ れから， $\beta$ が12.2， $\alpha_{2}$ が6.1， $\alpha_{1}$ が3.1で， $\gamma$-globulin は非常に低いょ5です. LDH の isozyme ではI，IIがわりあい多いんですが，I 型は $36 \%$ ですから多少多いといらだけで，あと，II，III，

IV, Vについては，だいたい正常です.

それから，Al-Pは，耐熱性フォスファターゼが あまりありませんで，熱失活するものがフォスフ アターゼの $87 \%$ というんですから，これはどこか ら出たのか，これで見るとだいたい肝臓ではない かと思いますが，組織像では何ともないといらこ とです. CRP は出ておりますが, ASLO が12単 位といら低い值ですが，r-globulin はあまり上が らなかったということが意味をもつのかどうか全 くわかりません。

他に何かございますでしょらか。宇藤君，ぞう ですか。

宇藤 このデータの中で1つわからないのは, noradrenaline のこれだけの異常高值はどのよう に説明されるのでしょらか。

林 石原先生, どうでしょうか, noradrenaline だけが高いのはどういうわけだろうかといらご質 問なんですが。

石原 catecholamineの分離定量の利点としまし て, adrenaline 或いは noradrenaline の増量から，
或る程度腫瘍の発生部位を知ることが出来すす。 即ち adrenaline と noradrenaline とが共に増加 している場合には腫瘍は副腎原発のものが多いと いわれています。一方, noradrenaline のみが著 明に増加している場合は，腫瘍は副腎以外のいわ ゆる異所性が疑われます。これは副腎髄質では noradrenalineを adrenaline 転換する酵素, 即ち, phenylethanolamine-N-methyltransferase が存在し, 副腎以外の組織ではこの酵素が久如す るためです。

山下この患者は, 精神安定剂を使っていると いらことからしますと，精神安定剤というのは測 定上の誤差としてカテコールアミンが高めに出る ことがありますので，そっちの影響も考光ておか なくてはいけないのではないかと思いすす。

田中 精神症状が盛んに出ているよ5なんです が，もちろん，これは一元的にいえなくて，他に ホルモンの関係があるかもしれませんし，電解質 の異常からかもしれませんし，いろいろな状態が 加わっていると思うのですけれども, 病理の解剖 の結果, 何か Hirn 飞器質的なものとか, そうい らのはなかったのでしょうか.

森脳の重さは $1410 \mathrm{~g}$ で, 普通よりちょっと重 いぐらいだったんですけれども，とくに髄膜にも 異常ありませんし，皮質・髄質も切り出した限り では，ミクロでもとくに異常ありませんでした。

石原 尿中の catecholamine の測定に際して, $\alpha$-メチル・ドーパ即ちアルドメット等の降圧剂を 使っている場合，他にテトラサイクリンなどの抗 生物質を使っている場合には低くなるんです。

それから，Krebs の endstadium でいろいろな ストレスによって，それに治療に対するストレス とか，心不全のような状態が続くと，逆に尿中の catecholamine が高くなるといわれています。

林この測定をした時点では，アルドメットは 使っていたようです.

石原 そとすると，元の影響があったというこ とが考党られるかもしれません。

林これは cushing の場合ですが，精神障害 は, 半分ぐらいは出ると成書に示されています 
ね. その大多数は depression だということです が，この患者の場合は非常に興奮していたようで す.却って逆のようでした。

宇藤 もら一つ扮聞きしたいのですが，これが 異所性の ACTH 分泌腫瘍であるとするならば, 17-OHCS がこれだけ上がっているのに，17-KS は汪ぼ正常範囲に止まっているということは，ど らいうふらに理解したらよろしいのでしょうか。

森 17-KS 子, 一応正常值は $3 \sim 8 \mathrm{mg} /$ day な んです.ですから，17-OHCS ほどはふえていま せんが，正常值の 2 倍ぐらいにふえていると考光 ていいと思います。

林 石原先生，これについてご意見ございます か.

石原 尿中の17-KS は主に副腎の androgen の 代謝産物です. 一方尿中の 17-OHCS は cortisol の尿中の代謝産物ですから, 異所性の ACTH 産 性の腫瘍であれば，これが副腎皮質を刺激し，多 量の cortisol が分泌され, その結果 17-OHCS が尿中に当然ふえてきます。
他方，17-KS が増えるような場合では，副腎の 中の zona reticularis むで拈かすような腫瘍があ れば, 尿中に増光ます。皇れから副腎性器症候群 の場合にも17-KS の著しい増加が認められます。

林 有難うございました。わかってしまってか らあとで検査データを見ますと，それらしいデー タが全部出ているわけでございまして，内分泌の ホルモンのデータを見なくとも, 糖尿病があっ て，低Kがあって，Naが高いというようなこと。 それから，白血球が増えていて好中球が増えてい ますが, eosin はさっぱりない、それから alkalosisがある.それぞれにわりあいはっきり病名を示 しているように思います。

ホルモン測定は䛊差が多すぎてよくわからない といらことではなくて，くり返しやっていただけ れば，も5少し早くわかった症例ではないかと， 私どもは思った次第です。

それでは長いこと有難うございました。これで 終わります。
頭蓋咽頭腫, craniopharyngioma は, 小児に多い 腫瘍の 1 つである.

症例は 6 歳の男児. 3 歳頃より肥満の傾向があり, 4 歳の時, 頭痛, 食欲不振を訴えたが間もなくこれら の症状は改善した.6歳の 時, 多食, 多尿括よび多飲 の傾向となり, 視力障害を 認め, 受診した. 頭部 $\mathrm{X}$ 線 像で, トルコ鞍に石灰化を 認め, CT スキャンであ石 灰化とcystic な特徽的な所見から, 頭蓋咽頭腫と診断 した.

頭蓋咽頭腫は, CT スキャンで石灰化が認められ, 造影剤により, capsule が enhance され, cysticな
型をとることが多い (Fitz, C.R., et ál: Radiology, $127: 687-691,1978$, 中村三郎 : 臨放, $21: 1063-$ 1071，1976. ). Cyst の内容のX線吸収值は髄液と同じ またはそれ以下であり，これはコレステロール結晶の ためであるという．腫瘍が 増大するにつれて, 視床下 部の症状を, あるいはモン ロー孔を閉塞して側脳室が 拡大し, 水頭症を和こすこ ともある. 本症は, 頭痛,

食欲不振および肥満を伴ない，ゆっくりと堌大し，尿 崩症を括こした頭蓋咽頭腫であるが, 診断のため CT スキャンは決定的な価值がある.

〔Dec.,23，1978〕（小児科 高橋 